\title{
Hizb ut-Tahrir i Danmark og Storbritannien: Samtidige transnationale og nationale tendenser
}

\author{
Af Kirstine Sinclair
}

\begin{abstract}
This article discusses national and transnational tendencies in the global Islamist enterprise Hizb utTahrir. In the article, it is argued that one can find simultaneous national and transnational tendencies Hizb ut-Tahrir depending on what level of the organisation one studies. Thus, the article distinguishes between four analytical levels: an ideological level, an organisational level, a practical memberoriented level and finally a media-related level. On the ideological level, Hizb ut-Tahrir is transnational, and this is also reflected in self-perceptions among members. However, on the organisational and practical levels, the tendency is that national branches are becoming more and more different according to their different contexts. And also the media-related level of the organisation internet activities and websites which by definition are not tied to territory and can address audiences world wide - turn out to be marked by local and national agendas and preferences to a growing extent.
\end{abstract}

Den islamistiske organisation Hizb ut-Tahrir, som opstod i Jerusalem i starten af 1950erne og siden er spredt til det øvrige Mellemøsten, Europa, Asien, Australien og USA, karakteriseres ofte som transnational grundet de ca. 40 nationale afdelinger verden over, organisationens tidlige og ihærdige aktiviteter på internettet og sidst men ikke mindst, organisationens ideologiske fokus på nødvendigheden af at forene den muslimske umma, det globale trosfællesskab, i en islamisk stat; kalifatet. Ved nærmere eftersyn viser det sig imidlertid, at der trods en ideologi, der ikke skeler til landegrænser eller nationale forskelle og velorganiserede internetaktiviteter, er mange elementer, der peger i retning af tiltagende national prægning i organisationens enkelte afdelinger. Eksempelvis resulterer organisationens struktur med opdelingen i nationale afdelinger $i$ at disse afdelinger præges af de forskellige nationale kontekster og udvikler sig i forskellige retning. Som vi skal se i det følgende, afspejles dette blandt andet $\mathrm{i}$ aktiviteterne på internettet.

I denne artikel vil jeg diskutere transnationale og nationale elementer i Hizb ut-Tahrirs danske og britiske afdeling og argumentere for, at Hizb ut-Tahrir er at betragte som et transnationalt foretagende, men at de enkelte afdelinger er stærkt prægede af deres nationale kontekster. Hvorvidt Hizb ut-Tahrir karakteriseres som transnational eller national afhænger således af, hvilket niveau af organisationen, 
man kigger på. De danske og britiske afdelinger er udvalgt på baggrund af deres geografiske nærhed, deres placering i Hizb ut-Tahrirs hierarki - den britiske er den største afdeling i Europa med ca. 1.500 medlemmer, og den danske er udråbt til regionalt hovedsæde for hele Skandinavien med ca. 150 aktive medlemmer - og fordi den britiske afdeling er ansvarlig for publicering og distribution af engelsksprogede publikationer, hvilket placerer denne afdeling i organisationens maskinrum så at sige. Jeg anvender Knut Kjeldstadlis definition af 'transnational', idet transnationale aktiviteter og organisationer i artiklen forstås som fænomener, der ikke findes mellem stater, men på tværs af grænser uden af den grund alene at være virtuelle. Aktivister og medlemmer af transnationale organisationer er altid forankret i specifikke steder (Kjeldstadli 2006:1).

Artiklen er udarbejdet på baggrund af et kapitel fra min ph.d.-afhandling (Sinclair 2010), og det empiriske materiale, der ligger til grund, udgøres af interviews med medlemmer og tidligere medlemmer i den danske og britiske afdeling af Hizb ut-Tahrir, samt studier af organisationens ideologiske materiale og øvrige publikationer samt online og on ground aktiviteter i perioden 20032010. Selv om det er vanskeligt at opdele en organisation med en holistisk ideologi i forskellige niveauer i en analyse, er dette ikke desto mindre hvad jeg forsøger i denne artikel. Jeg ser på Hizb utTahrir på et ideologisk niveau, et organisatorisk niveau, et praktisk niveau og endelig med hensyn til medieaktiviteter og i særdeleshed udviklingen i partiets brug af hjemmesider på internettet. Mit argument er som følger: Mens Hizb ut-Tahrirs ideologi og internetaktiviteter bærer tydelige transnationale karakteristika, er afdelingerne i Danmark og England påvirket af de nationale sammenhænge inden for hvilke de opererer, og tendensen er, at såvel den danske som den britiske afdeling bliver mere og mere nationalt orienterede.

\section{Det ideologiske niveau}

I Hizb ut-Tahrirs kanoniske litteratur er især to begreber centrale for karakteristikken af Hizb ut-Tahrirs ideologi som transnational. For det første er der grundlæggeren Taqi al-Din al-Nabhanis forståelse af det islamiske kalifat, og for det andet, opfattelsen af umma, det globale trossamfund af muslimer. Den ideologiske fortolkning af disse begreber er blevet forklaret og bekræftet af både danske og britiske repræsentanter for Hizb ut-Tahrir (interviews med de danske medierepræsentanter i hhv. 2003 og 2009 
og med den britiske medierepræsentant i 2003).

Etableringen af et islamisk kalifat er af afgørende betydning for Hizb ut-Tahrir og er selve målet med deres politiske virke. For Hizb ut-Tahrir er kalifatets genetablering ensbetydende med en forening af alle muslimer uanset etnicitet, sprog og traditioner. Tilmed anskues kalifatets genetablering som en befrielse fra vestlig imperialisme og kolonialisme (al-Nabhani 1953a: 75 -76). Desuden er det kommende kalifat en retfærdig stat ('Draft Constitution', 1953b: 140ff) med fastsætte regler for valg af leder og definerede rettigheder for mindretal osv., og det er en god stat med et socialt system, der varetager alle menneskelige behov. Grundlaget for staten er islam og den fromme levevis praktiseret af muslimer. Nabhani forklarer:

The only way to establish the Islamic State is to carry the Islamic Message and to work towards the resumption of the Islamic way of life, which necessitates taking the Islamic countries as one Ummah (1953b: 236)

Ifølge al-Nabhani, bør alle muslimske lande forenes i kalifatet, fordi alle muslimer tilhører det samme trosfællesskab og alle forsøg på opdeling i separate nationer med nationale traditioner er kunstige. Når kalifatet først er blevet genetableret vil muslimer automatisk søge til kalifatet. Dette vil følge det mønster, der gjorde sig gældende under de første kaliffer. Under overskriften: 'Molding [sic] People into one Ummah', forklarer al-Nabhani:

The inhabitants of these countries [the countries included in the caliphate by the Umayyads] varied in ethnicity, language, religion, traditions, customs, laws and culture. They naturally differed from each other in mentality and attitude. Therefore, the process of moulding these countries together and of uniting them into one single Ummah adopting the same Deen, language, culture and laws was a colossal task. Success would be a tremendous and extraordinary achievement. This happened solely through Islam and was only achieved by the Islamic state. Once those people were identified by the banner of Islam and ruled by the Islamic State, they became a single Ummah, which is the Islamic Ummah. (1953b: 157, oversat af Hizb 
ut-Tahrir i Storbritannien i 1998).

Logikken fra dette perspektiv er, at alle forskelle kan overvindes, når muslimer og ikke-muslimer bringes sammen i en islamisk stat. Der gives fire begrundelser herfor: For det første vil indførelsen i islams lære få ikke-muslimer til at konvertere, for det andet er islam sandheden, og folk genkender sandheden, når de konfronteres med den. For det tredje vil samspillet mellem muslimer og ikkemuslimer i de nyligt erobrede områder få ikke-muslimer til at erkende, hvor meget lykkeligere muslimer er, hvilket vil bringe dem til islam, og endelig vil disse nyligt omvendte muslimer opleve en "radical change" fra en "dismal situation to a better one" (al-Nabhani 1953b: 158). Ifølge al-Nabhani vil islam og det islamiske kalifat omfavne alle forskelle og overkomme alle udfordringer og konflikter mellem muslimer. Transnationalisme i en sådan holistisk ideologisk opfattelse vil dermed sige, at alle ting, der adskiller muslimer og alle forskelle mellem muslimer kan og bør afvises. Ifølge Hizb ut-Tahrir er det muslimske samfund altid allerede en helhed, der er blevet krænket af kunstige, koloniale grænser og undertrykkere, og løsningen på verdens tilstand er at skabe en stat, der kan befri muslimer fra pålagte begrænsninger. Og i arbejdet for dette mål lever Hizb ut-Tahrir, befrielsespartiet, op til sit navn.

\section{Det organisatoriske niveau}

Hizb ut-Tahrir har en hierarkisk struktur med den internationale leder, amiren, øverst. Under ham er tre niveauer, hvoraf to er administrative udvalg. Det første niveau er det provinsielle eller nationale med en national ledelse, det andet består af lokaludvalg, der dækker byområder eller byer, og endelig det tredje og sidste niveau omfatter talrige studiekredse med ca. 5 medlemmer og en leder (mushrif). Det internationale lederskab udpeger medlemmerne i de nationale udvalg under en leder (mu'tamad), og de nationale udvalg udpeger medlemmerne af lokaludvalgene. Lederen af et lokaludvalg kaldes naqib. Ideelt set består de nationale udvalg af mellem fem og ti personer, mens de lokale udvalg har fire medlemmer (Taji-Farouki 1996: 116). Imidlertid afviger nye afdelinger typisk fra dette. Eksempelvis var det, da den danske afdeling var i opstartsfasen i slutningen af 1990'erne, meget lettere at opnå fuldt medlemskab og blive tildelt en betroet stilling end det ville være i en mere etableret afdeling, alene fordi partiet manglede hænder og ressourcer (interview med tidligere medlem i Danmark, 2009). Som regel er alle instrukser dikteret oppefra i hierarkiet, og alle udvalg har pligt til at melde tilbage med 
oplysninger om aktiviteter og udviklinger inden for deres område.

Det internationale lederskab er kendt for at formulere specifikke retningslinjer og strategier til de enkelte nationale udvalg. De nationale udvalg har imidlertid en særlig plads i hierarkiet, idet de har myndighed til at handle på vegne af det internationale lederskab, hvis det synes nødvendigt, så på dette niveau er et element af autonomi eller uafhængighed af den internationale organisation til stede (TajiFarouki 1996: 119). Det britiske nationale udvalg har ved flere lejligheder fravalgt at oversætte og omdele løbesedler fra det internationale lederskab, da det blev vurderet, at materialets indhold ville blive misforstået i en britisk kontekst og således skabe problemer. Et godt eksempel er en løbeseddel med en opfordring til drab på jøder, som i 2003 kostede den danske medierepræsentant en dom for racisme. Denne løbeseddel blev aldrig omdelt i Storbritannien (interview med tidligere medlem af det britiske nationale udvalg, 2008). Men som sagt er det generelle billede, at det internationale lederskab i Amman fortsat er dominerende og flertallet af aktiviteter derfor er de samme i alle nationale afdelinger. Det internationale lederskab definerer ikke kun partiaktiviteter men også prioriteringen af disse, hvilket resulterer i en stærk sammenhæng mellem de praktiske og organisatoriske niveauer i Hizb ut-Tahrir. Et godt eksempel på, hvordan den britiske afdeling fortsat adlyder ordrer fra Amman og således også et eksempel på den stærke hierarkiske struktur i Hizb ut-Tahrir, kan ses i et strategidokument fra 2005.

Dokumentet kaldet 'Strategier for aktiviteter i Vesten' afslører, hvordan den internationale ledelse anskuer muslimsk tilstedeværelse i vestlige lande, og hvordan de rådgiver partimedlemmer i Storbritannien til at henvende sig til muslimer og ikke-muslimer på de britiske øer med henblik på rekruttering. Dokumentet består af tre sider med overvejelser om muslimsk tilstedeværelse i vesten på grundlag af partiets ideologi og metoden til distribuering af partiets budskab ved at uddanne masserne og mere specifikt gennem "assimilation of Muslims and [by making] Muslims realise that they are part of the great Umma" (Hizb ut-Tahrir 2005: 2).

I dokumentet hedder det, at situationen for muslimer i vesten ændrer sig i kraft af at et stigende antal muslimer har slået sig ned udenfor muslimske majoritetslande permanent, et faktum, der gør det muligt at tale om muslimske minoritetssamfund i de vestlige lande. Hizb ut-Tahrirs ledelse så fortsat i 2005 muslimske majoritetslande som modtager og mål for alle aktiviteter og som hjemsted for det 
kommende kalifat. Det hedder i dokumentet: "The party has not extended its action to the lands of the unbelievers" (Hizb ut-Tahrir 2005: 1), hvorved man kan forstå, at aktiviteterne i de europæiske grene af organisationen ikke betragtes som en del af partiets kerneaktiviteter. Dette er interessant i betragtning af størrelsen af den britiske afdeling og vigtigheden af aktiviteterne på de britiske øer med hensyn til at distribuere partiets engelsksprogede materialer og etablering af nye afdelinger. Dette udsagn vidner om, at til trods for at Hizb-u-Tahrir i Storbritannien spiller en uhyre væsentlig rolle i udbredelsen af Hizb ut-Tahrirs ideologi og aktiviteter, og for eksempel er ansvarlig for al oversættelse af partimateriale til engelsk, så anerkender den internationale ledelse ikke aktiviteter, som ikke sigter specifikt på genindførelsen af kalifatet i et muslimsk domineret område. Strategidokumentet er således et eksempel på, at de transnationale elementer i ideologien med særlig vægt på kalifatets genoprettelse, er delvist på kollisionskurs med aktiviteterne i den største europæiske afdeling af organisationen, nemlig den britiske.

Den internationale ledelse betragter aktiviteterne i de europæiske afdelinger som noget, der skal føre til gennemførelsen af et kalifat i et muslimsk land, hvilket kan ses som et udtryk for transnationalisme. Ledelsen i Amman giver fortsat anvisninger og formulerer strategier for partiets europæiske afdelinger, hvilket vidner om en streng og centraliseret kontrol med afdelingerne og medlemmerne i alle af de 43 nationale afdelinger arbejder fortsat for oprettelsen af et kalifat $i$ et muslimskdomineret område. Mens den britiske gren forventes at være den mest aktive med hensyn til tværnationale aktiviteter (udgivelse og distribution samt højtstående medlemmers rejseaktiviteter, hvilket vi kommer tilbage til), er dens aktiviteter og betydning i 2005 fortsat klassificeret som perifere af den internationale ledelse.

Der findes dog i strategidokumentet også er andet budskab, nemlig dette at det tillægges stor betydning at styrke muslimers identitet og religiøse bevidsthed i muslimske minoritetssamfund. Dette er et centralt budskab for Hizb ut-Tahrirs afdelinger i vesten, fordi det giver mulighed for at europæiske og andre vestlige grene af partiet kan fokusere på rekruttering og arbejde blandt deres nationale og lokale muslimske minoritetsgrupper mere eksplicit.

Med hensyn til nationale perspektiver anerkender strategidokumentet muslimsk tilstedeværelse som permanente i vesten, hvilket måske nok er en sen erkendelse (dokumentet er som nævnt fra 2005), men 
som ikke desto mindre giver plads til en ny måde for Hizb ut-Tahrirs britiske afdeling at nærme sig Storbritanniens muslimske befolkning. Med strategidokumentet blev der givet grønt lys for at betragte muslimer i Storbritannien som briter, hvilket vil sige som individer, der ikke forventes at forlade landet. Dette betød, at Hizb ut-Tahrir i Storbritannien fra 2005 kunne tage emner af specifik interesse for britiske muslimer op og bruge den britiske sammenhæng mere eksplicit i partiets propaganda eksempelvis ved at inddrage sager af interesse for minoriteter såsom den britiske diskriminationslovgivning.

\section{Det praktiske niveau}

På det praktiske plan kan Hizb ut-Tahrir karakteriseres som transnational i den forstand, at alle interne partiaktiviteter (studiekredse, produktion og offentliggørelse af skriftligt materiale, afholdelse af arrangementer osv.) samt eksterne aktiviteter rettet mod offentligheden (deltagelse i debatter, offentlige møder, demonstrationer, distribution af skriftligt materiale osv.) er de samme i alle afdelinger. Der er også eksempler på medlemmer, der rejser mellem nationale afdelinger med henblik på at udbrede ideologien og inspirere til flere aktiviteter. Et eksempel herpå er Maajid Nawazs aktiviteter i Danmark i 2000. I sin egenskab af at repræsentere det britiske nationale lederskab kombineret med hans pakistanske baggrund og urdukundskaber, rejste Nawaz til Danmark i 2000 for at hjælpe den danske afdeling med at oprette studiekredse blandt pakistanske unge i Danmark. Nawaz hævder også at have været medvirkende til at oprette afdelinger i Malaysia og Pakistan, hvilket talspersoner for begge disse afdelinger imidlertid har afvist. Der er ingen tvivl om, at Nawaz, på grund af hans anciennitet i den britiske gren, sin stilling som medlem af det britiske nationale lederskab, hans pakistanske baggrund og hans politiske og oratoriske evner, har været medvirkende til at sprede Hizb ut-Tahrir budskab fra Storbritannien til Danmark, Pakistan, Egypten (Nawaz blev fængslet for sine Hizb ut-Tahrir-aktiviteter i Egypten i 2002 og sad fængslet i fire år) og muligvis andre lande også, og at han har spillet en central rolle i promoveringen af transnationale kollektive indsatser i form af rejseaktiviter, vidensdeling, foredrag og generelle appeller til fælles aktiviteter i Europa, Mellemøsten og Sydasien (Kjeldstadli 2006: 2). Der er imidlertid heller ingen tvivl om, at selvsamme Nawaz, der forlod Hizb ut-Tahrir i 2007 og i dag aktivt propaganderer for anti-ekstremistiske synspunkter i tænketanken Quilliam Foundation, har fortalt sin historie vidt og bredt og derved bidraget til opfattelsen af Hizb ut-Tahrir som en 
organisation baseret på transnational kommunikation og transnationale aktiviteter.

Før Nawazs tid blev Hizb ut-Tahrir bragt til Europa af andre personer. Hizb ut-Tahrir har eksisteret i Europa siden 1960'erne, men først da partiaktivist og prædikant Omar Bakri Mohammed oprettede studiekredse i London-området i midten af 1980'erne vandt organisationen større udbredelse. Et årti senere, i midten af 1990 'erne begyndte Fadi Abdullatif at uddele flyveblade under partiets navn i København. I dag har de to afdelinger som nævnt henholdsvis ca. 150 og ca. 1500 medlemmer. Af disse medlemmer er kun en lille brøkdel involveret i aktiviteter på tværs af landegrænser. Når man spørger tidligere medlemmer om rejseaktiviteter og kontakt med medlemmer $\mathrm{i}$ andre lande, viser sig følgende mønster: Hizb ut-Tahrir tilskynder alle medlemmer til at sprede partiets idéer så meget og så bredt som muligt, og medlemmer med tilknytning til muslimske majoritetslande opfordres til at drage fordel af sådanne bånd og distribuere materiale og idéer, når de rejser til Pakistan, Bangladesh eller arabiske lande osv. Men langt størstedelen af medlemmerne rejser ikke uden for deres eget land som en del af deres engagement i partiet, og kun højtstående medlemmer i Storbritannien er blevet sendt til udlandet for at hjælpe med oprettelsen af nye afdelinger. Situationen er noget anderledes i Danmark, da der har været regelmæssig interaktion med den tyske afdeling. De fleste adspurgte tidligere medlemmer var kun i kontakt med medlemmer i andre lande, der blev betragtet som venner. Medlemmer af de nærliggende europæiske afdelinger bistår hinanden og deltager eksempelvis i hinandens konferencer, og den britiske afdelinger havde og har stadig en central rolle i distribution af engelsksproget materiale til andre afdelinger. Alt $\mathrm{i}$ alt synes den britiske afdeling at have været forbundet med andre afdelinger $\mathrm{i}$ højere grad end den danske. Bortset fra samarbejdet mellem de tyske og danske afdelinger, der blandt andet har bestået $\mathrm{i}$ at danske medlemmer har modtaget undervisning i partiets litteratur, har den danske afdeling så vidt vides ikke haft megen kontakt med andre afdelinger.

Ifølge mine respondenter har de ikke som medlemmer lagt særlig vægt på hverken nationale politiske dagsordener eller transnationale aspekter af Hizb ut-Tahrirs aktiviteter Derimod tegner der sig et billede af, at de som medlemmer udelukkende har fokuseret på deres egne præstationer og resultater for partiet. For at udbrede partiets ideer mest effektivt har medlemmer distribueret materiale og diskuteret ideologien i deres personlige netværk med familie, venner og kolleger, ligesom de har benyttet sig af adgang til andre sociale områder - for eksempel universitetsstudenterforeninger, mødregrupper, åbne 
debatarrangementer osv. (interview med den britiske kvindeafdelings medierepræsentant Nasreen Nawaz 2003, og tidligere medlemmer i Danmark og Storbritannien 2009).

Tidligere medlemmer fortæller, at de som medlemmer har trukket på deres personlige netværk og relationer, hvilket betyder at spredningen af partiets idéer og den deraf følgende rekruttering af nye medlemmer i første omgang er formet af den dominerende etniske eller sociale gruppe i en afdeling. Når britisk-pakistanere henvender sig til kolleger, personer med pakistansk baggrund i deres engelske hjemby eller i deres families landsby i Pakistan, og dansk-arabere i Danmark henvender sig til andre med arabisk baggrund, er resultatet, at Hizb ut-Tahrir udvikler sig i overensstemmelse med særlige sociale (ofte familiebaserede) og sproglige mønstre. Ydermere er det udbredt i Hizb ut-Tahrir, at medlemmer indgår ægteskab med andre medlemmer, hvilket underbygger karakteren af partiets netværk som relativt lukket og nemt at underlægge social kontrol fra studiekredsledere, regionale ledere og i sidste ende de nationale ledere. Der er altid en bror eller en søster i det hierarkiske niveau over et medlem, der kender den pågældendes familie eller nære omgangskreds. Således jonglerer Hizb ut-Tahrirs medlemmer i Danmark og England med flere politiske dagsordener og spørgsmål om nationale tilhørsforhold og gruppetilhørsforhold i deres arbejde for partiet udover en følelse af et personligt ansvarlig for partiets udvikling.

\section{Medierelaterede aktiviteter}

Ved første øjekast er Hizb ut-Tahrirs tilstedeværelse på internettet udtryk for organisationens globale appel og tilstedeværelse. Men udviklingen i de danske og britiske afdelingers brug af hjemmesider fremhæver nationale forskelle, og demonstrerer, hvorledes begge afdelinger prioriterer forskelligt $\mathrm{i}$ forhold til nationale kontekster og politiske dagsordener. Hizb ut-Tahrir har været repræsenteret med hjemmesider på 'the World Wide Web’ siden 1997 og de tidlige aktiviteter her samt partiets kompetente internetkommunikation er blevet bemærket af forskere (Taji-Farouki 1996; Baran 2004). Imidlertid har mine studier af udviklingen af partiets britiske og danske websider vist, at det er relativt nyt, at partiets hjemmesider er begyndt at blive opdateret regelmæssigt, hvormed det først er for nyligt, at internettet kan betragtes som et effektivt værktøj til kommunikation med den bredere offentlighed, mellem medlemmer og i rekrutteringsøjemed. Desuden forholder de nye danske og britiske hjemmesider sig til det omgivende samfund på en mere direkte måde end tidligere set. Denne udvikling ses mest eksplicit 
efter 2005, da den britiske afdeling begyndte af brande sig selv som 'Hizb ut-Tahrir Britain'; HTB.

Som med al internetbaseret aktivitet og udvikling af hjemmesider er der sket en masse med Hizb utTahrirs internetsider siden starten i 1997. Den første side, hizb-ut-tahrir.org, indeholdt links til flere sider på forskellige sprog, som blev ajourført fra tid til anden med en stigende mængde af materiale i løbet af de første par år. Derpå blev flere links inaktive og siderne på alle andre sprog end engelsk og arabisk syntes at blive nedprioriterede. Desuden var intet af indholdet af nyhedsmæssig værdi. Den internationale hjemmeside og de nationale sider denne linkede til - og stadig linker til - ser ud til at fungere mere som en opslagstavle end noget andet. Dette efterlader det indtryk, at det er vigtigt for Hizb ut-Tahrir til at have listen over sprog med det ene formål at signalere, at Hizb ut-Tahrir er en international organisation.

Efter 2005 er der imidlertid sket noget. Bag adresserne 'khilafah.dk' og især 'hizb.org.uk' er der blevet sat en ny standard for Hizb ut-Tahrirs internetkommunikation på europæiske sprog. Her behandles samfundsrelaterede emner og nyheder, ligesom siderne har introduceret interaktiv kommunikation med brugerne, invitationer til partiarrangementer og så videre. Det tidsmæssige sammenfald mellem Hizb ut-Tahrirs britiske afdelings branding af sig selv som 'HTB' og den nye internetbaserede kommunikation er ikke tilfældig. Begge dele følger i kølvandet på det nævnte strategidokument også fra 2005. HTB taler via den nye hjemmeside, som de selv er ansvarlige for driften af uafhængigt af den internationale ledelse i Jordan, direkte til et britisk muslimsk publikum på en tidssvarende måde. Siden 2005 har HTB stået for et tættere samspil med et læsende og engageret publikum via websiden, hvilket ses på de talrige invitationer til pressekonferencer og demonstrationer og på hjemmesiden temaer sådan 'What Can I Do' og 'In the Community'.

En lignende udvikling er set i den danske afdelings brug af hjemmesiden 'khilafah.dk' siden 2006. Denne side har eksisteret parallelt med den officielle danske side hizb-ut-tahrir.dk, som er linket til den internationale partihjemmeside, men i modsætning til den danske version af den internationale og officielle hjemmeside, indeholder 'khilafah.dk' taler og foredrag af prominente medlemmer, og siden 2006 er khilafah.dk blevet opdateret langt oftere end hizb-ut-tahrir.dk. Hjemmesiden hizb-ut-tahrir.dk blev ikke opdateret en eneste gang i 2008, og i 2009 kunne nyt materiale om konferencer, politiske 
analyser og kommentarer kun findes på khilafah.dk. 'Khilafah.dk' indeholder den danske udgave af Khilafah-magasinets arkiv og artikler skrevet efter magasinets ophør i 2002. Desuden indeholder denne side links til Hizb ut-Tahrir-materiale på dansk, engelsk og arabisk og er alt i alt langt mere brugervenlig og informativ end hizb-ut-tahrir.dk-siden.

\section{Fra 'Hizb ut-Tahrir i vesten' til 'Hizb ut-Tahrir af vesten'}

Set i lyset af Hizb ut-Tahrirs mål at genskabe kalifatet $i$ et muslimsk land er strategidokumentet fra 2005 interessant. Selv om det er angivet i dokumentet, at Hizb ut-Tahrir ikke har udvidet sine aktiviteter til 'de vantros lande', er det ikke desto mindre anerkendt, at tilstedeværelsen af muslimske minoriteter i Vesten er permanent, og at partiets afdelinger i de vestlige lande således kan målrette en del af deres aktiviteter til lokale trosfæller. Dokumentets understregning af, partiet er forpligtet til at informere muslimer i vesten om deres religion og sørge for, at de er imod de stærke og negative påvirkninger af det omgivende vestlige samfund, er også central. Ikke mindst fordi der i understregningen ligger, at Hizb ut-Tahrirs medlemmer skal fokusere på at tjene deres samfund og gå foran som gode eksempler, og at dette i sig selv er en måde at vedligeholde og styrke deres muslimske identitet i minoritetssituationen. Denne anerkendelse og opfordring fra det internationale lederskab i Jordan modsvares af indholdet af hjemmesiden 'hizb.org.uk', hvor Hizb ut-Tahrirs britiske afdeling kalder sig selv HTB og introducerer temaer som 'In the Community', underforstået: Det muslimske minoritetssamfund i Storbritannien. Det er muligvis en overvurdering af en detalje, men det ser ud til, at indførelsen af brandet HTB, som er blevet fulgt op af den amerikanske gren nu kaldet Hizb ut-Tahrir Amerika, HTA, er et bevis på, at Hizb ut-Tahrirs afdelinger fokuserer på deres nationale publikum og er begyndt at tænke på sig selv som ikke bare 'i' deres specifikke vestlige land, men 'af' deres vestlige land. Et dansk eksempel på denne udvikling er temaet for Hizb ut-Tahrirs seneste danske konference i oktober 2010, som netop var at muslimer skal være rollemodeller i det danske samfund.

Som nævnt fungerer Hizb ut-Tahrirs internationale hjemmeside primært som en opslagstavle med envejskommunikation og forældet materiale og inaktive links. Tilstedeværelsen på internettet med denne side må derfor have tjent en anden funktion end kommunikation mellem medlemmer og øvrige interesserede. Den internationalt orienterede hjemmeside har været brugt til at offentliggøre en liste over sprog, der repræsenterer de lande, hvor Hizb ut-Tahrir var og er aktiv, og dermed sende et signal 
om, at Hizb ut-Tahrir er en vigtig, transnational aktør. Interessant nok har flere vestlige forskere accepteret Hizb ut-Tahrirs selvrepræsentation som sandheden om partiet, når det gælder Hizb ut-Tahrirs beskrivelse af sig selv som transnational i betydningen stor og indflydelsesrig (se eksempelvis TajiFarouki 1996 eller Baran, 2004). Man kunne argumentere for, at henvisninger til Hizb ut-Tahrir som 'transnational' på mange måder svarer til at acceptere partiets egen repræsentation af sig selv såvel som selvforståelsen fundet i ideologien. Hizb ut-Tahrir opfatter sig selv som havende en universel ideologi og på den baggrund som værende i stand til at samle alle muslimer i deres fremtidige kalifat. Denne selvforståelse udtrykkes i en lang liste af sprog på en forældet hjemmeside og begrebet 'transnational' har tilsyneladende været vestlige forskeres navn for det.

En anden konklusion, der kan drages af nærværende undersøgelse af Hizb ut-Tahrirs aktiviteter og holdning til medierne er, at lokale afdelinger reagerer forskelligt på de forskellige nationale kontekster og politiske dagsordener, som de indgår i og endvidere, at den interne struktur i organisationen, herunder hvem der besidder hvilke stillinger, er vigtig for, hvordan den enkelte afdeling vælger at bruge medierne og tiltrække opmærksomhed til sit arbejde. Siden 2001 og især siden 2005 har to helt forskellige udviklinger fundet sted i de danske og britiske afdelinger. Den britiske har igen fokus på sin egen dagsorden efter at have flirtet med forskellige 'undercover' internetinitiativer og offentlige optrædener, mens den danske afdeling synes at være blevet mere åben overfor samarbejde med andre muslimske organisationer, som det eksempelvis sås med samarbejdet om et debatarrangement i kølvandet på Karikaturstriden i 2006.

Det hævdes ofte, at Hizb ut-Tahrir og andre islamistiske transnationale organisationer kommunikerer med medlemmer og den bredere offentlighed via deres hjemmesider, og at de har været meget progressive og dygtige, når det gælder om at tiltrække nye rekrutter via web-sider (Bowen 2004; Baran 2004; Brandon 2009). Men internationale studier viser også, at: "the internet can support and facilitate but never completely replace direct human contact" (Sageman 2004: 163; Stevens og Neumann 2009: 13). Tilsyneladende er dette argument også relevant i forhold til Hizb ut-Tahrirs aktiviteter. Frem til 2005-06 er nye rekrutter hovedsageligt fundet gennem direkte kontakt med medlemmer i forbindelse med møder, demonstrationer og andre aktiviteter (interviews med tidligere medlemmer i Danmark og 
Storbritannien, 2008 og 2009).

At Hizb ut-Tahrir udvikler sig gennem personlige relationer forklarer både de transnationale elementer i organisationen og de nationale forskelle. Partiets idéer rejser med personer fra land til land - det være sig via migration (arbejdsmigration, flugt osv.), private ferierejser eller som et resultat af en bevidst partistrategi. Og efterhånden som medlemmer bosætter sig i nye dele af verden, etableres nye Hizb utTahrir-afdelinger. Udbredelsen af partiets idéer i forlængelse af personlige relationer er afgørende for udviklingen af nationale forskelle. Så længe Hizb ut-Tahrir udbredes gennem personlige netværk og de fleste individuelle netværk består af folk med samme baggrund som dem selv, vil det være de samme etniske grupper inden for en Hizb ut-Tahrir-afdeling, der fortsætter med at være den mest dominerende. Derfor er forsøg på at karakterisere Hizb ut-Tahrir som enten transnational eller eksplicit dansk eller britisk ikke så frugtbare som man kunne forvente. Disse etiketter er simpelthen ikke dækkende for aktiviteterne og orienteringen i organisationen. Mens hver afdeling stadig reagerer på ordrer og regler fra det internationale lederskab, er de meget pragmatiske og reflekterede, når det kommer til personlige præferencer, national politik og lovgivning og konkurrence fra andre muslimske grupper i deres nationale kontekst. Dette resulterer i, at den danske og den britiske afdeling langsomt bliver mere og mere påvirket af deres nationale omgivelser.

\section{Konklusion}

Hizb ut-Tahrir har afdelinger i over 40 lande og der er ideologiske såvel som medierelaterede aktiviteter, der er klart grænseoverskridende og transnationale. Men med hensyn til det organisatoriske niveau betyder opdelingen i nationale afdelinger og disse afdelingers øgede uafhængighed af det internationale lederskab især siden 2005, at de transnationale tendenser er mindre dominerende end de nationale på dette niveau. Dette mønster ses også på det praktiske niveau i organisationen. Blandt ordinære medlemmer er partiaktiviteter prægede af nationalt og lokalt arbejde, personlige relationer og individuelle præferencer. For eksempel har der været meget lidt kontakt mellem den danske og britiske afdelinger på trods af den korte afstand mellem de to lande. Den danske medierepræsentant har forklaret, at afdelinger kun samarbejder, hvis det findes nødvendigt (interview med Chadi Freigeh, 2009). Tilsyneladende var samarbejde nødvendigt, da en repræsentant fra den britiske afdeling talte ved en dansk konference i 2007 og igen i 2010, og forud herfor, da Maajid Nawaz som nævnt rejste til 
København for at hjælpe med at oprette en studiekreds for personer med pakistansk baggrund i 2000.

Hvis vi sammenligner den ringe grad af transnationalitet på det organisatoriske og praktiske niveau i organisationen med den kendsgerning, at de nye, nationalt drevne hjemmesider er langt mere funktionelle end de internationale hjemmesider, så er det rimeligt at hævde, at begrebet 'transnational' ikke dækker alle Hizb ut-Tahrirs aktiviteter. Til trods for at kommunikationen på internettet ikke er begrænset af nationale grænser, er tilstedeværelse på internettet ikke lig med transnationale aktiviteter i praksis. Hizb ut-Tahrirs aktiviteter på internettet er både transnationale og nationale, men det er de nationale hjemmesider, der repræsenterer interaktion med et levende og engageret publikum. I betragtning af de organisatoriske, praktiske og medierelaterede niveauer synes en nationaliseringsproces at finde sted i Hizb ut-Tahrirs danske og britiske afdelinger. Men det er fortsat den transnationale og ideologiske ramme, der knytter alle eksisterende afdelinger sammen, og som gør fortsat rekruttering mulig. Uden den transnationale, ideologiske ramme for aktiviteterne ville Hizb utTahrir ganske simpelt ikke have nogen politisk appel, intet budskab, ingen at befri.

\section{Referencer}

Baran, Z, 2004: Hizb ut-Tahrir - Islam's Political Insurgency, The Nixon Center, Washington D.C.

Bowen, J. R., 2004: "Beyond Migration: Islam as a Transnational Public Space" in Journal of Ethnic and Migration Studies 30(5): 879-894.

Brandon, J., 2009: “Al-Qa ida's Involvement in Britain's "Homegrown" Terrorist Plots” in CTC Sentinel, 2: 10-12.

Hee, M., 2008: Afhopperen - Seks år i Hizb ut-Tahrir, Jyllands-Postens Forlag, København.

Hizb ut-Tahrir, 2010: Hizb ut-Tahrir, http://www.hizb.org.uk/hizb/images/PDFs/HT_media_pack.pdf

- 2005: Strategies of Action in the West, oversat fra arabisk af tidligere medlem af Hizb ut-Tahrir i Storbritannien i 2009. 
Kjeldstadli, K., 2006: Transnational Social Movements, ikke publiceret konferencepaper: 1-24.

Lewis, P., 2004: Young, British and Muslim, Continuum, London.

- 1994: Islamic Britain. Religion, Politics and Identity among British Muslims, I.B.Tauris, London.

Mandaville, P., 2007: Global Political Islam, Routledge, New York og London.

- 2005: "Sufis and Salafis: The Political Discourse of Transnational Islam" in: Remaking of Muslim Politics. Pluralism, Contestation, Democratization, red. Hefner, Princeton University Press, Princeton and Oxford, 302-325,

- 2002: "Towards a Critical Islam: European Muslims and the Changing Boundaries of Transnational Religious Discourse" in Muslim Networks and Transnational Communities in and across Europe, red, Nielsen og Allievi, Brill: Leiden, 127-145.

- 2001: Transnational Muslim Politics: Reimagining the umma, Routledge, New York and London.

Al-Nabhani, T.,1953a: Concepts of Hizb ut-Tahrir, .

- 1953b: The Islamic State, http://www.khilafah.dk/boger/IslamicState.pdf.

- 1953c: Political Thoughts, http://www.khilafah.dk/boger/Pthoug.pdf.

- 1953d: The Ruling System in Islam, http://www.khilafah.dk/boger/RulingSystem.pdf.

- 1953e: Structuring of a Party, http://www.khilafah.dk/boger/StructParty.pdf.

- 1953f: The System of Islam, http://www.khilafah.dk/boger/sysislam.pdf.

(C) Forfatteren og Tidsskrift for Islamforskning, ISSN 1901-9580, publiceret 27-4-2012 
Nawaz, M., 2008: In and Out of Islamism, The Quilliam Foundation, London.

Nielsen, J. S., 2002: "Transnational Islam and the Integration of Islam in Europe" in Muslim Networks and Transnational Communitties in and across Europe, red. Nielsen og Allievi, Brill, Leiden, 28-51.

Roy, O., 2004: Globalized Islam, Columbia University Press, New York.

Sageman, M., 2004: Understanding Terror Networks, University of Pennsylvania Press, Philadelphia.

Simonsen, J. B., 2001: Det retfcerdige samfund. Om islam, muslimer og etik, Samleren, København.

Sinclair, K., 2010: The Caliphate as Homeland: Hizb ut-Tahrir in Denmark and Britain, Upubliceret ph.d.-afhandling, Syddansk Universitet.

- 2008: "Islam in Britain and Denmark: Deterritorialized Identity and Reterritorialized Agendas" in Journal of Muslim Minority Studies, 28(1): 45-52.

Sinclair, K., Grøndahl, M. og T. Rasmussen., 2003: Hizb ut-Tahrir i Danmark: Farlig Fundamentalisme eller uskyldigt ungdomsoprør?, Aarhus Universitetsforlag, Aarhus.

Stevens, T. og P. Neumann., 2009: Countering Online Radicalisation. A Strategy for Action, The International Centre for the Study of Radicalisation and Political Violence (ICSR), London.

Taji-Farouki, S., 1996: A Fundamental Quest. Hizb al-Tahrir and the Search for the Islamic Caliphate, Grey Seal, London.

Wiktorowicz, Q., 2005: Radical Islam Rising. Muslim Extremism in the West, Rowman \& Littlefield, Lanham, Maryland. 


\section{Om forfatteren}

Præsentation: Kirstine Sinclair (f. 1976). Adjunkt i moderne Mellemøststudier ved Syddansk Universitet. Arbejder især med muslimske minoritetsorganisationer i Vesteuropa - herunder islamistiske organisationer. Forsvarede i 2010 sin ph.d.-afhandling om Hizb ut-Tahrir kaldet The Caliphate as Homeland: Hizb ut-Tahrir in Denmark and Britain, og har siden redigeret bogen Lived Space: Reconsidering Transnationalism among Muslim Minorities (Peter Lang, 2011) om muslimske minoriteter i Vesteuropa.

http://www.sdu.dk/ansat/sinclair 